\title{
T. W. Rolleston's Ireland through a Polish Prism
}

\author{
Michael McATEER \\ Pázmány Péter Catholic University (Budapest, Hungary) \\ Department of English Literatures and Cultures \\ michael.mcateer@btk.ppke.hu
}

\begin{abstract}
A founding member of the Irish Literary Society, an early member of the Gaelic League, and a leading figure in the Irish Co-operative Movement, Thomas William Rolleston was one of the most notable figures in movements for Irish cultural and economic revival during the late nineteenth/early twentieth century. Rolleston also had a keen interest in German literature and culture, developed originally from the four years that he lived in Wiesbaden and Dresden between 1879 and 1883. This experience granted him some appreciation of conditions that obtained in Germany prior to the outbreak of the First World War, including Prussian-Polish relations. In 1917, Rolleston published a significant pamphlet assessing Irish-British relations during the decades preceding the 1916 Rising in Ireland as compared with relations between Prussia and Poland over the same period. Rolleston rejects a widespread view in Ireland that the moral authority, which the British Government had accorded to itself as a defender of the rights of small nations in the war against Germany, had been fatally compromised by its willingness to countenance Polish independence while continuing to oppose Irish independence. This essay considers the contrasts that Rolleston draws between Ireland and Poland in 1917 in the light of his general views on the Irish language question and Irish politics during the 1900s.
\end{abstract}

Keywords: Rolleston, Ireland, Poland, First World War, 1916 Rising

\section{Rolleston on Ireland in European Context}

Despite an impressive range of achievements and activities over several decades in Ireland, Germany, and London during the era of the Irish Revival, Thomas William Rolleston has been largely neglected in the field of Irish criticism. There is not a single book-length critical study devoted to him in the one hundred years since his death in 1920. The only biographical account is to be found in his son's somewhat sketchy work of 1939 (Rolleston 1939). Conor Morrissey's recent discussion of Rolleston in the context of Protestant involvement in Irish nationalism during the 1900s is a welcome development, though he covers but a brief period in the writer's/activist's 
life in relation to a wide range of other figures from the period (Morrissey 2019, 2044). Symptomatic of the critical neglect that Rolleston has suffered, his pamphlet of June 1917, Ireland and Poland: A Comparison, has been largely disregarded even though it appears at a critical time in modern Irish history, just over a year after the Irish rebellion of 1916 and during the third year of the First World War. This essay addresses the arguments that Rolleston lays out in Ireland and Poland in the light of this historical context and with regard to the following considerations. First, there is the significance of Rolleston's standing in Irish literary and political circles for evaluating the pamphlet's content. Second, there is the pamphlet's uniqueness as a publication in comparing the political circumstances of Ireland under British rule with those of Polish regions under Prussian rule during the decades preceding the outbreak of the First World War and the 1916 Rising in Ireland. Third, the pamphlet is significant for the arguments that it makes in contrasting land and language policies in British-governed Ireland with those exercised in Prussian-governed Polish territories during this same period.

Rolleston's Ireland and Poland is striking as much for its timing as its content. It enters public domain just over a year after the defeated Irish uprising of April 1916, the subsequent execution of the rebel leaders, the arrest of around three thousand five hundred people, and the deportation of over one thousand eight hundred participants to internment camps or prisons in Britain (Ferriter 2005, 154). Yet it also appears at a time in which the last of these prisoners were released under the orders of the British Government, with Prime Minister Lloyd George calling together an Irish Convention in June 1917 in the hope of finding a solution to the Irish political situation against the backdrop of the ongoing war in Europe (Lee 2008, 163). When regarded in this context, Ireland and Poland demonstrates just how deeply political developments in Ireland following the 1916 Rising were tied up with the course of events during the First World War. Rolleston was an Irishman who had lived in Germany for a number of years in the early 1880s while also being involved with such notable Irish cultural and economic organizations as the Irish Literary Society and the Irish Co-operative Movement. ${ }^{1}$ He was therefore well positioned to offer a cogent assessment of the Irish situation in a Central European context during the last years of the War.

In her major study of the place of Poland in Irish nationalist discourse from the early eighteenth to the early twentieth century, Róisín Healy suggests that, given how Rolleston was employed in the Department of Information in London during the War years, the British Government may have sponsored the publication of

1 Rolleston lived in Wiesbaden and Dresden between 1879 and 1883. He co-founded the Irish Literary Society with W. B. Yeats and D. J. O'Donoghue in London in 1891. Through his friendship with the founder of the Irish Agricultural Organization Society (IAOS), Horace Plunkett, Rolleston became an important figure in the Irish Co-operative Movement, supporting the work of the Department of Agriculture and Technical Instruction after it was set up in 1900. 
his pamphlet as a counter to Irish protests over the contrasting policies that the Government was adopting towards Ireland and Poland from 1917 (Healy 2017, 253). Healy points to an increase of resentment across the spectrum of Irish society in 1917 when, as part of the Entente Powers, Britain declared its full support for an independent Polish state. This new position stood squarely at odds with the Government's Irish policy, where Home Rule had still not been agreed upon even after the huge upsurge in nationalist anger at the British Government after the defeat of the 1916 rebellion. By 1917, Lloyd George's Government agreed to implement Home Rule but only on condition that the predominantly Protestant north-east of Ireland would opt out for a period of at least six years (Healy 2017, 250-252). Healy shows that comparisons between Ireland and Poland had been made in the Irish press since the outbreak of the First World War in 1914 as part of a longer history of Irish identifications with Poland that dated back to the early eighteenth century. She points to debates in the Freeman's Journal in late 1915-early 1916, in which reports of Prussian suppression of Polish people were taken as indications that a victory of the Central Powers might very well enforce the suppression of Irish rights under German rule rather than bring about Irish independence. One of the most significant interventions in this debate was made by Patrick Pearse in December 1915, just over four months prior to his leading the Irish rebellion in Dublin. Healy draws attention to Pearse's provocative claim that, horrific as the war was, it was still not worse than the long history of Polish enslavement by Russia and Irish enslavement by England. Pearse wondered if the war might prove to be the context within which both countries could achieve their freedom (Healy 2017, 245-246).

\section{Rolleston on Irish Language and Political Questions}

The contribution of Rolleston's pamphlet to the comparisons made during the years of the First World War between circumstances in Ireland and those in Poland was significant for two reasons. First, Rolleston's views commanded respect, even among those Irish nationalists who strongly disagreed with him, because of his prominence in those cultural and economic revival movements that gathered momentum in Ireland during the 1900s. Second, he had acquired strong proficiency in the German language when living in Wiesbaden and Dresden for four years in the early 1880s, so it was not that easy to dismiss his arguments as biased or uninformed. In 1894, W. P. Ryan described how Rolleston came together with others to initiate the Irish Literary Society in the Southwark district of London. The Society was founded upon the Southwark Club, inaugurated by Galway native Francis A. Fahy and Offaly native John T. Kelly in 1883. The Southwark Club had been promoting Irish literature, primarily through translations of old Irish-language literary works, in a part of London with a significant Irish emigrant 
community (Ryan 1970, 11-18). Along with D. J. O'Donoghue, Rolleston met up with W. B. Yeats at Yeats's residence in Chiswick to take the work of the Southwark Club on to a new level, founding the Irish Literary Society under the shadow of the British Museum near the end of December 1891 (Ryan 1970, 35-36). Rolleston became the Honorary Secretary of the Society, and, while he did not support the view that a new literary movement exclusively in the Irish language was feasible, he did earnestly argue that Irish literature in English could succeed in creating a distinctively national literature by drawing upon the inheritance of the Irishlanguage oral and literary traditions. This view was laid out in an article published in The Irish Weekly Independent in 1896, one that Rolleston's son Charles quotes in full in his biography of his father (Rolleston 1939, 11-23).

Given that one of the questions arising when comparisons were drawn between Ireland and Poland was that of language rights, Rolleston's position on the Irish language is a matter of importance. He was certainly at odds with his friend Douglas Hyde, a fellow graduate of Trinity College Dublin whom he supported in the founding of the Gaelic League in 1893. Unlike Rolleston, Hyde was fervently committed to reviving Irish as a living vernacular throughout the country. Despite their difference of opinion, Rolleston's views on the language question would have been taken seriously, particularly since he himself had advocated an interest in the Irish language and Irishlanguage literature through his involvement with the National Board of Education, originally established by the British Government for Ireland in 1831 (Lyons 1973, 82). In August 1900, Rolleston criticized the attitudes to the Irish language among the various school committees throughout Ireland that ran under the auspices of the National Board, arguing that the enormous decline of the Irish language through the course of the nineteenth century was not brought about by England. On the contrary, Rolleston asserted with some degree of justification that it was the broad mass of the Irish people themselves and their leaders who "cooperated eagerly with the National Board of Education in digging the grave of the ancient tongue" (Rolleston 1900a, 1). A few months earlier, Rolleston praised some recent English translations of old Irish-language works, describing Standish Hayes O'Grady's Silva Gadelica (1892) as "the greatest monument of Gaelic scholarship" since the days of Irish antiquarians Jeremiah O'Donovan and Eugene O'Curry from the early to mid-nineteenth century (Rolleston 1900b, 2). In his biography, Charles Rolleston explains that his father's scepticism towards the revival of Irish as a living vernacular was not borne out of any hostility to the language. It was simply his belief that, because the language had fallen into disuse, it lacked the words for a wide range of modern objects and activities. New Irish-language words would have to be invented if the language was to become an effective means of communication in modern times, and, when grafted onto the old language, the new vocabulary would "deprive the latter of that individuality and character which a language can only acquire satisfactorily by a process of natural and continuous evolution" (Rolleston 1939, 23). 
Rolleston's political thought on Ireland during the years of campaigning for Home Rule is perhaps best encapsulated in a pamphlet that he published in 1900, Ireland, the Empire, and the War (Rolleston 1900c). So taken was the editor of the All Ireland Review with the article that Standish James O'Grady gave over a full page of his newspaper to reprinting passages taken from it (O’Grady 1900, 5). This pamphlet was published at a time when hostility towards Britain as an imperial power took on a new shape among Irish nationalists in the form of a protest movement against the British war with the Boers in South Africa. Irish opposition was manifested in the pro-Boer Transvaal Committee that was founded in December 1899, leading an anti-recruitment campaign to dissuade young Irishmen from serving in British Army regiments that were then fighting the Boers (McCracken 1989, 50-53). The most striking aspect of this pro-Boer campaign was the contingent of five hundred men who travelled under the command of John MacBride to fight as an Irish Brigade alongside the Boers against British forces from September 1899 to September 1900. Donal McCracken provides a book-length study of the history of this Irish Transvaal Brigade (McCracken, 1999).

In responding to these attitudes and circumstances, Rolleston criticized what he saw as a fundamental inconsistency in the political attitudes that obtained among Home Rule nationalists in Ireland. On the one hand, there prevailed a spirit of rebellion in which Britain and its Empire was consistently the subject of scorn among supporters of Irish Home Rule or complete Irish independence. Yet, at the same time, the Irish Parliamentary Party sat at Westminster Parliament, took an oath of allegiance to the British Crown, and made political alliances with English Parties, while enormous numbers of Irish youth took up positions in the British Imperial Civil Service or in the British Armed Forces (O’Grady 1900, 5). Given Rolleston's conviction that the existence of a completely independent Irish nationstate had no historical precedent and was not the desire of the majority of the Irish people in any case, he proposed that the pursuit of Home Rule was the only sensible and viable option. Instead of maintaining some kind of grassroots appeal through an anti-British rhetoric of anti-Imperialism, however, Rolleston argued that Irish politicians and civic leaders should fully embrace Ireland's position within what he termed "the Anglo-Celtic Empire," in the pursuit of an Irish Home Rule parliament (O'Grady 1900, 5). He admitted that the history of the Empire had been "stained by many errors and many crimes," but he put these down largely to "a detestable English failing, the inability to think that anything can be successful and admirable and worthy of being taken quite seriously which is not English” (O’Grady 1900, 5). Rolleston appeals to Irish supporters of Home Rule to distinguish between "English" and "British," arguing that while the English "oppressed and plundered" Ireland for many centuries, the British Empire has done "nothing but good" for the country, the Union flag being as much a symbol of Ireland as of England or Scotland (O’Grady 1900, 5). 


\section{Land and Language in Ireland and Poland}

Róisín Healy highlights the importance of the historical moment during which Rolleston's 1917 pamphlet appears for the appreciation of its arguments. Her emphasis suggests that these arguments were primarily contingent upon the circumstances that obtained in Ireland at that time in the context of the ongoing European war, particularly the fall-out from the 1916 uprising. A close scrutiny of the pamphlet, however, also raises the alternative possibility that Rolleston's views in 1917 were actually consistent with his attitude to the revival of the Irish language or to Irish nationalist opposition to Britain many years earlier during the period of the Boer War.

Two points should be noted in relation to this question before turning to the substance of the pamphlet itself. First, Rolleston's scepticism towards the identifications made between Ireland and Poland in 1917 is something he makes clear from the outset: "as though the peoples of these two countries were suffering the same kind of oppression, the same injustice, the same denial of the right of every man to live and prosper in his own land on equal terms with his fellowcitizens in every other part of the realm" (Rolleston 1917, 3). The barely-concealed tone of exasperation in these words is nothing new. It recalls his lamentation over seventeen years earlier at how his fellow Irishmen "cheer on every foe of the Empire without the slightest consideration of the merits of their cause" (O'Grady $1900,5)$. Second, Rolleston would have been the last person to indulge that hatred of all things German which became rampant in England during the First World War. Having lived in Germany for four years, having learnt the language, having introduced the poetry of Walt Whitman to German audiences, having written a biography of Gotthold Ephraim Lessing and translations of Richard Wagner, Rolleston's sympathy for German culture obviously ran deep. ${ }^{2}$ He was bold enough to defend the achievements of German literature in a piece that was published in The Hibbert Journal during the first months of the war in October 1914. Rolleston argued that the German literature of Dichter was sharply distinguished from the culture promulgated through the state education system from the universities down. He also regarded the militarism and organizational bureaucracy at work in Germany during the years leading into the war as a predominantly Prussian phenomenon. Rolleston maintained that the stories of Rudolf Lindau, the dramas of Gerhard Hauptmann, or even the philosophy of Friedrich Nietzsche had nothing to do with the militant nationalism of Germany. If anything, they stood at odds with the militaristic spirit

2 Rolleston entered into a significant correspondence with Whitman (Frencz 1951). He was instrumental in making Whitman's work more widely appreciated among literary circles in Dublin and London, publishing an important essay on the poet in German in 1871, one translated into English in 1893 (Rolleston 1971, 230-239). Rolleston also published his biography of Lessing in 1889, an English translation of Wagner's Tannhauser in 1900, and a translation of The Tale of Lohengrin in 1913. 
of popular German literature as it appeared in the years leading into the First World War, exemplified for Rolleston in the mass popularity of a novel like Bernhard Kellermann's 1913 Der Tunnel in Germany (Rolleston 1914-1915, 82-88).

In Ireland and Poland, Rolleston describes an anti-Polish policy adopted by the German Government since the 1880s. He asserts that between 1886 and 1906 this Government spent on average the equivalent of one million pounds sterling to buy out Polish landowners and plant ethnic Germans in their stead. He mentions that in 1904 the German Government banned Polish people from building new farmhouses without a licence. He describes an even more oppressive law coming into force in 1908 through which "in clear defiance of the German Constitution, the Prussian Government actually took powers and were voted funds - from taxation paid by Poles and Germans alike - for the compulsory expropriation of Polish owners against whom nothing whatever could be alleged except their non-German nationality" (Rolleston 1917, 7-8). The result of these government policies was that Polish people living and working on their land had come to be regarded as a nuisance who ought to be replaced by Germans. Rolleston sets this German policy in stark contrast to that of the British Government's approach to the land question in Ireland during the late nineteenth-early twentieth century period. He acknowledges that most of the land of Ireland had been confiscated from the native Irish people in wars of conquest during the seventeenth century and granted to an aristocracy mainly of English descent. He also asserts, however, that over the same period as Prussian subordination of rural Polish peoples, the British Government's policy had been one of transferring the effective ownership of land from the Anglo-Irish aristocracy to the Gaelic Irish peasantry. In support of this view, he mentions the terms of various British Government Land Acts from the 1870s that resulted in Irish tenants only being liable for rents that were fixed under law, with the freedom to sell their leases whenever they wished. Rolleston also points to the British Government's land purchase scheme that enabled Irish tenant farmers to buy their lease-holdings in fixed instalments at a rate lower than the rent due. He observes that almost twothirds of the rural Irish population had become the owners of their land as a result, with the remainder of tenants enjoying conditions almost equal to that of outright ownership (Rolleston 1917, 9).

Another matter of great importance to Irish nationalists that Rolleston addresses in the pamphlet was that of language. He begins by drawing attention to the foundation of the National University in 1908 as a solution to the question of British Government funding for a Catholic University in Ireland, noting that while the National University was open to persons of all creeds, its Government was primarily in the hands of the Irish Catholic hierarchy (Rolleston 1917, 13). He also highlights knowledge of the Irish language as a requirement for matriculation in the National University. Rolleston presents a stark contrast between British and Prussian government policies on the Irish language in the nineteenth century. He 
observes an official policy of weakening the use of Polish within the territory of Poland that Prussia acquired after the Treaty of Vienna in 1815. Relying on William Harbutt Dawson's The Evolution of Modern Germany (1908), Rolleston asserts that no Polish was permitted to be used at public meetings, that since 1873 German alone was taught in national schools, that German had to be the language of instruction wherever half of the students could understand it, that a decree of 1899 forbade teachers even to speak Polish within their own family circles, and that Polish literature could be confiscated and its possessor imprisoned if this literature was deemed to carry the least trace of pro-Polish propaganda (Rolleston 1917, 14).

Rolleston sets this account of a deliberate Prussian Government policy to suppress the Polish language against the situation obtaining in Ireland. He states that the Irish language was spoken by up to half of the population in the 1830s. This is followed by a crucial and contestable claim: "No restrictive measures were in force against it" (Rolleston 1917, 15). This statement ignores the fact that the Irish language had no legal status in nineteenth-century Ireland under the Union (nor, indeed, under the Irish Parliament of the eighteenth century), meaning that all native Irish speakers were forced either to acquire knowledge of English or to depend upon people fluent in English if they were to have any recourse to the law. Rather astonishingly, Rolleston makes no mention of the Great Famine that afflicted Ireland during the 1840s when accounting for the decline of Irish as a spoken vernacular subsequently. Instead, he explains this decline in terms of the attitudes to the Irish language among Irish political leaders, beginning with Daniel O'Connell in the 1820s and the National Board of Education set up by the Government in 1831. Observing that the census of 1911 recorded just 16,000 people in Ireland who spoke Irish only, Rolleston asserts that the abandonment of Irish by the majority of Irish people took place with the approval of Irish political leaders and the vast majority of the Irish Catholic clergy (Rolleston 1917, 16). He quotes from Douglas Hyde's introduction to his 1890 collection of Gaelic folk stories, Beside the Fire, in support of this view (Hyde 1890, xliii-xliv). Turning to Hyde's effort to revive the Irish language with the foundation of the Gaelic League in 1893, Rolleston notes its successes, particularly the translation of Irish texts and the compilation of the first modern Irish-language dictionary. He observes also that the British Government did not block these efforts but instead permitted the teaching of Irish in elementary schools, with grants being made available for the training of Irish language teachers and over 12,000 pounds sterling being paid annually from the British Government Exchequer in support of the Irish language (Rolleston 1917, 17-18). Rolleston presents these official support schemes as evidence of a benign British Government response to efforts to revive the Irish language at the end of the nineteenth century, offering a sharp contrast to that of the Prussian Government's policies concerning the Polish language.

Considering these arguments that Rolleston makes over the land question and the language question in Ireland and Poland, it is evident that his position was 
strongly consistent with views he expressed long before the First World War. British Government policies on land ownership had brought about a situation by the 1900s whereby Irish agricultural tenants had become effective owners of the land that they worked; the movement to revive traditional Irish culture in the form of the Irish language at the end of the nineteenth century encountered no British Government opposition but did receive financial support. These developments, as presented by Rolleston, were entirely consistent with his belief in Ireland, the Empire, and the War from 1900 that the Irish Home Rule movement should proceed on the basis of fully accepting Ireland's powerful position within the British Empire, through which it could acquire the best of both worlds: Irish governance of Irish affairs coupled with the benefits of a strong connection to the British Imperial administration through Ireland's continued membership of the United Kingdom. Furthermore, Irish circumstances within the United Kingdom in the 1900s represented for Rolleston a stark contrast with Polish circumstances under German rule in the Prussiancontrolled region of the former Polish-Lithuanian Empire. His pamphlet essentially amounts to a refutation of the Irish nationalist charge against British Government hypocrisy in accepting the case for Polish independence in 1917 yet refusing to recognize the case for Irish independence much closer to home. Rolleston makes this refutation on the basis of a demonstration of the gulf between British policies towards Ireland from the late-nineteenth century and Prussian policies towards Poland over the same period.

\section{Misreadings in Ireland and Poland}

There are three serious weaknesses in the argument of Ireland and Poland. First, comparisons between the situation of Ireland and that of Poland were not only drawn by Irish nationalists. In fact, none other than the British Prime Minister himself, Henry Asquith, insinuated the comparison in a speech delivered in Dublin on 25 September 1914, exhorting Irishmen to join the war effort against Germany and its allies: "How can you Irishmen be deaf to the cry of the smaller nationalities to help them in their struggle for freedom, whether, as in the case of Belgium, in maintaining what she has won, or, as in the case of Poland and the Balkan States, in regaining what they have lost or in acquiring or putting upon a stable foundation what has never been fully theirs?” (Asquith 1914, 31). If the point of Rolleston's pamphlet was to accuse the Irish nationalist movement of opportunism in making an open identification between Ireland and Poland during the year following the 1916 Rising in Dublin, then he would have been obliged to direct this same accusation against Prime Minister Asquith's carrot dangling during the first months of the War in 1914. That Rolleston ignores this matter is evidence of the fact that, as an employee of the British Ministry of Information during the War years, he was not 
writing from a position of objective indifference. Second, if Prussian mistreatment of the Polish people under its jurisdiction was as bad as Rolleston claimed, why did the British Government not agree to recognize the legitimacy of Polish independence until 1917 as part of the Entente Powers, and then only provisionally so? Jeffrey Mankoff indicates why this was the case. The British Government was vacillatory in its Polish policy, even internally divided on the question. Influenced by Polish statesman Roman Dmowski, the Foreign Office inclined to the view that a strong, independent Polish nation-state would stabilize Eastern Europe; fearing Russian territorial ambitions, the War Office preferred to rely on Germany rather than Poland in preventing any Russian advance westward in post-First World War circumstances (Mankoff 2008, 763). A major concern for the British during the years of the War was that Polish independence could jeopardize Britain's alliance with Russia since a new Polish nation-state would have to incorporate a territory that was part of the Russian Empire. The British even considered that independent Poland switching its alliance from the Entente Powers to the Central Powers was a significant risk (Mankoff 2008, 743-745). Mankoff points out that as late as Tsar Nicholas II's abdication in March 1917, just three months prior to the publication of Rolleston's pamphlet, the British Government still had not decided its policy on Poland definitively (Mankoff 2008, 756).

The third and possibly most fatal weakness in the argument of Ireland and Poland is that Rolleston relies entirely on one source only for his information on recent Polish experience under Prussian rule: William Harbutt Dawson's 1908 book The Evolution of Modern Germany. Running to almost 500 pages, this is a very reliable study providing a far-ranging and in-depth analysis of Germany's economic and political rise to power over the course of the post-Napoleonic era and especially since the age of Bismarck. However, its discussion of the Polish question is confined almost entirely to the last chapter, and it is upon this that Rolleston depends for his information in his Ireland and Poland pamphlet. It is clear that Rolleston is highly selective in maintaining an image of Prussian aggression towards Poland that he sets in contrast to Britain's benign treatment of Ireland during the decades preceding the First World War. He neglects to mention, for example, that Dawson does not argue that German treatment of Polish peoples was uniformly and consistently oppressive. The author is certainly critical of Prussian policies towards the Polish people but not because they were completely despotic in character; rather because they were consistently inconsistent, Prussian rulers having "throughout vacillated between yielding suavity and unbending rigour" (Dawson 1908, 470). This could well characterize Britain's Irish policies during the late nineteenth century and into the beginning of the twentieth. The Land Acts of 1870, 1881, 1885, 1887, and 1903 all worked progressively towards Irish tenant ownership of land. Yet these were accompanied by Coercion Acts in 1881 and 1887 under which many agitators for Irish tenant rights and many Irish constitutional political leaders (including 
Irish Party leader Charles Stewart Parnell) found themselves imprisoned at various points and for varying durations.

In The Evolution of Modern Germany, Dawson draws attention to a marked increase in the Polish presence within German territories that was a significant factor in Prussian coercive measures towards Polish landownership and the Polish language, a consideration that Rolleston ignores in his pamphlet. Dawson points out that in 1860 Polish workers were non-existent in the industrial districts of Westphalia and the Upper Rhine; by the early 1900s, their numbers had risen to two hundred thousand (Dawson 1908, 469). Furthermore, Rolleston also chooses to ignore one of the most blatant acts of discrimination against the Poles under Prussian rule to which Dawson alludes in his study. This is put simply by a member of the Prussian Lower House, Dr Jazdzewski: "No Pole can plead his own cause before the courts in his mother-tongue, and should he wish to employ it before the administrative authorities, he is not heard" (Dawson 1908, 472). The reason for Rolleston choosing to overlook this example is obvious: the same situation obtained in the British-governed legal system in Ireland with regard to the Irish language, and had done so for several centuries. Given that his own father was a respected magistrate in County Tipperary, Rolleston would have been fully aware of this fact.

\section{Conclusion}

Despite these failings, Rolleston's Ireland and Poland remains an enormously significant pamphlet for several reasons. It appears at a crucial time in modern Irish history, in the aftermath of the British Government's disastrous mishandling of the 1916 rebellion in Dublin, swelling the support-base for Irish independence in a way not seen since the time of Daniel O'Connell in the 1830s and early 1840s. It was published in the same month that Prime Minister Lloyd George called the Irish Convention, representing the last attempt by the British Government to find agreement among nationalists and unionists to finally implement an Irish Home Rule parliament. In relation to this specific context, Rolleston's pamphlet might be described as the final intellectual defence of the Home Rule position from one who had been closely associated with the formation of some of the literary/cultural movements that gave impetus subsequently to a number of the leaders of the 1916 Rising: Patrick Pearse, Thomas MacDonagh, and James Connolly. More than anything, it illustrates how the contest for the political future of Ireland after 1916 was tied up with the course of events during the First World War. Lloyd George had taken over from Asquith in December 1916; March 1917 saw a major upheaval within the Entente Powers when Tsar Nicholas abdicated following a socialist takeover in St Petersburg; April 1917 saw America enter the war on the British, French, and Russian side. The temporary recognition by the Entente Powers of Poland's 
case for independence has to be understood within these circumstances, and such recognition obviously lent strength to the Irish nationalist case for an independent republic. Rolleston had lived in Germany for a number of years and became an important authority in Britain on German cultural affairs in his position as editor of the German language and literature section of The Times Literary Supplement from 1908 (Welch 1996, 500). Coupled with his involvement in Irish literary affairs and with the Irish Co-operative Movement, this experience enabled him to articulate a broadly pro-British Government perspective on Irish nationalist identifications with the cause of Polish independence. His approach was one that contextualized recent Irish history engagingly in relation to Central Europe against the backdrop of the ongoing fallout from the 1916 Rising.

\section{Works Cited}

Asquith, Herbert Henry. 1914. "A Speech in Dublin, 25 ${ }^{\text {th }}$ Sept., 1914.” In The War, Its Causes and Its Message: Speeches Delivered by the Prime Minister, AugustOctober 1914, 27-33. London: Methuen.

Dawson, William Harbutt. 1908. The Evolution of Modern Germany. London: T. Fischer Unwin.

Ferriter, Diarmuid. 2005. The Transformation of Ireland. London: Profile Books.

Frencz, Horst, ed. 1951. Whitman and Rolleston: A Correspondence. Bloomington: Indiana University Press.

Healy, Róisín. 2017. Poland in the Irish Nationalist, Imagination, 1722-1922: AntiColonialism within Europe. Houndsmills, Basingstoke: Palgrave Macmillan.

Hyde, Douglas, ed. and transl. 1890. Beside the Fire: A Collection of Gaelic Folk Stories. London: David Nutt.

Lee, Joseph. 2008. The Modernisation of Irish Society, 1848-1918. Third edition. Dublin: Gill \& Macmillan.

Lyons, F. S. L. 1973. Ireland since the Famine. Second Edition. London: Fontana.

Mankoff, Jeffrey. 2008. "The Future of Poland, 1914-1917: France and Great Britain in the Triple Entente.” The International History Review vol. 30, no. 4: 741-767.

McCracken, Donal P. 1989. Forgotten Protest: Ireland and the Anglo-Boer War. Belfast: Ulster Historical Society. 1999. MacBride's Brigade: Irish Commandos in the Anglo-Boer War. Dublin: Four Courts Press.

Morrissey, Conor. 2019. Protestant Nationalists in Ireland, 1900-1923. Cambridge: Cambridge University Press.

O'Grady, Standish. 1900. "The Great Enchantment: A Remarkable Pamphlet.” All Ireland Review March 17: 5. 
Rolleston, Commander C. H. 1939. Portrait of an Irishman: A Biographical Sketch of T. W. Rolleston. London: Methuen.

Rolleston, T. W. 1900a. “A. E. and Fiona MacLeod.” All Ireland Review August 25: 1. 1900b. "Some Recent Translations from the Gaelic of Old Irish Legends." All Ireland Review April 28: 2.

1900c. Ireland, the Empire, and the War. Dublin: Sealy, Bryers and Walker. 1914-1915. "Literature and Politics in Modern Germany." The Hibbert Journal: A Quarterly Review of Religion, Theology, and Philosophy, eds. L. P. Jacks and G. Dawes Hicks vol. 13: 82-88.

1917. Ireland and Poland: A Comparison. London: T. Fisher Unwin.

1971. "Rolleston on Whitman." Transl. from German by Alfred Foreman and Richard Mauric Bucke. In Walt Whitman, ed. Milton Hindus, 230-239. London: Routledge.

Ryan. W. P. 1970 [1894]. The Irish Literary Revival: Its History, Pioneers and Possibilities. New York: Lemma.

Welch, Robert, ed. 1996. The Oxford Companion to Irish Literature. Oxford: Clarendon Press. 